\title{
Effect of Associated Vaccines on the Interference between Newcastle Disease Virus and Infectious Bronchitis Virus in Broilers
}

Duthor(s)
Cardoso $\mathrm{WM}^{1 *}$
Aguiar Filho $\mathrm{JL}^{2}$
Romão $\mathrm{JM}^{3}$
Oliveira WF $\mathrm{WF}^{2}$
Salles RPR
Teixeira RSC
Sobral MHR
1 Professor, Veterinary Medicine College,
Ceara State University
2 Graduate student, Veterinary Sciences,
Ceara State University
3 Undergraduate student, Veterinary
Medicine College, Ceara State University

\section{Mail Address}

William Maciel Cardoso

Av. Rogaciano Leite, 200- Apt ${ }^{\circ} 1303$ - Bl. Tulipe Bairro Salinas

60.810-000. Fortaleza, Ceará,Brazil

Phone/Fax: $\quad 55$ (85) 32411307

or $55(85) 31019848$

or 55 (85) 99894742

E-mail: william.maciel@uol.com.br and josueromao@yahoo.com.br

\section{Keywords}

Infectious bronchitis, Newcastle disease, vaccines, viral interference.

\section{ABSTRACT}

The phenomenon of viral interference between live vaccines against Newcastle Disease and infectious bronchitis has been reported since the 50's and many researchers have reported its prejudicial effects on avian immunization. Therefore, this study evaluated the effect of associated vaccines on the interference between Newcastle disease virus (NDV) and infectious bronchitis virus (IBV) in broilers. There were 400 broiler chicks divided into five groups. The groups were submitted to mono or polyvalent vaccinations against IBV and NDV, except for the non-vaccinated control group (CG). Sera were collected at 35 and 45 days of age and submitted to serologic tests to assess antibody levels. It was observed the occurrence of interference in the immune response against NDV by the use of associated vaccines to NDV and IBV; however, the group that was immunized with commercial combined vaccines (IBV+NDV) presented antibody titers to NDV similar to the group that was given only vaccine against NDV. We concluded based on these preliminary studies that the interference of IBV on the immune response against NDV depends also whether the association between the two vaccines is done just before vaccination or in the manufacturing laboratory.

\section{INTRODUCTION}

Newcastle Disease (ND) and infectious bronchitis (IB) are important diseases in the poultry industry and cause great losses (Tu et al., 1998; King \& Cavanagh, 1991). Control involves the use of biosecurity procedures and vaccination. In order to reduce costs, vaccination using two or three vaccines simultaneously became a common practice in poultry production, such as a combined vaccine against ND and IB. Earlier studies have reported that infectious bronchitis virus (IBV) interferes with the immune response against Newcastle disease virus (NDV) (Raggi \& Lee, 1964; Bracewell et al., 1972; Thornton \& Muskett, 1975).

Nowadays, Gelb et al. (2004) restart discussions about viral interference by means of evaluating IBV and NDV replication using a new detection technique, the Reverse Transcription Polymerase Chain Reaction (RT-PCR). Smith (2002) and other authors report productivity losses related to viral interference in broiler flocks in the southeast region of the United States, resulting in economic losses to producers. Thus, the objective of this work was to evaluate the effect of associated vaccines on the immune response against Newcastle disease and infectious bronchitis in broilers.

\section{Material and Methods}

\section{Birds}

The study was performed in experimental broiler houses at the 
Cardoso WM, Aguiar Filho JLC, Romão JM, Oliveira WF, Salles RPR, Teixeira RSC, Sobral MHR
Veterinary College of Ceara State University. There were 400 one-day-old chicks from breeders aged 42 weeks. The birds were not vaccinated in the hatchery and were raised until 50 days of age at a density of $10 \mathrm{birds} / \mathrm{m}^{2}$. Standard management procedures were provided, including ad libitum water and feed.

\section{Treatments and bird vaccination}

The birds were divided into five experimental groups ( $n=80$ birds/group): a non-vaccinated control group (CG) and groups vaccinated at 8 days of age ( $G 1, G 2$, G3-ABV and G3-CVLP). G1 and G2 were vaccinated against IB and ND, respectively. G3-ABV was given IB and ND vaccines combined just before vaccination. G3CVLP was vaccinated using a commercial IB-ND vaccine that is combined during manufacturing.

Immunization was performed through instillation of $0.03 \mathrm{~mL}$ by ocular route in each bird. All vaccines were obtained from the same laboratory and vaccinations were performed by the same workers. ND-vaccines administered to G2, G3-ABV and G3-CVLP were prepared using the strain HB1 (titer $10^{6.5}$ ) while $\mathrm{G} 1$ and G3-ABV-immunization against infectious bronchitis was performed with the strain $\mathrm{H}_{120}$ (titer 103.5). G3-CVLP was given an IB vaccine prepared with the strain Massachussetts Ma5 (titer 103.5).

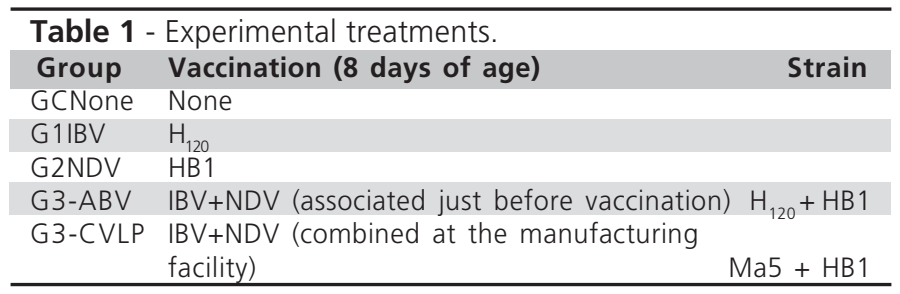

\section{Blood collection and serological tests}

Blood collections in the control group were carried out at 1, 25, 35 and 45 days of age in order to assess maternal antibody levels against IBV and NDV. The other groups were submitted to blood collections at 35 and 45 days of age. Blood samples were drained from the brachial vein and sera were separated, identified and frozen at $-20^{\circ} \mathrm{C}$ until the serological tests were performed.

Serum samples were analyzed by Hemagglutination inhibition test $(\mathrm{HI})$ to detect antibodies against NDV according to Alexander et al. (1983) and by a commercial indirect ELISA (enzyme-linked immunosorbent assay) to detect anti-IBV antibodies (Kirkegaard \& Perry Laboratories - KPL).
Effect of Associated Vaccines on the Interference between Newcastle Disease Virus and Infectious Bronchitis Virus in Broilers

\section{Statistical Analyses}

The titers obtained by ELISA and HI were submitted to analysis of variance using the statistical package SAS (SAS, 1999). Data on antibody titers were analyzed after logarithmic transformation $\left(\log _{10} x+1\right)$. Means were compared using the Student's t test at a significance level of $5 \%$.

\section{RESULTS AND DISCUSSIONS}

The control group presented antibody titers against NDV that decreased from GMT 4500 in the first day to basal levels at 45 days of age. Antibody titers against IBV were null throughout the experiment. Graph 1 shows NDV and IBV antibody curves of the control group.

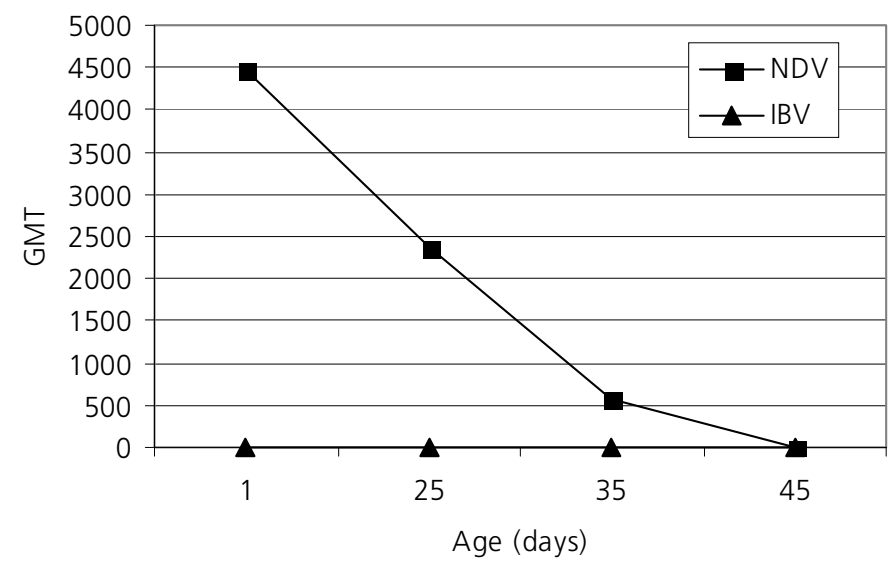

Graph 1 - Titers of antibodies against Newcastle disease virus and Infectious bronchitis virus in the control group.

The progressive decrease in antibody titers against NDV until basal levels is in accordance to findings reported by Gelb et al. (1998) who showed that maternal antibodies decreased to approximately zero after few weeks. The reduction in NDV antibodies and the absence of IBV antibodies indicated that there was no IBV or NDV field challenge during the experiment. Graph 2 shows the antibody titers against IBV of groups G1, G3-ABV and G3-CVLP at 35 and 45 days of age.

Anti-IBV antibody titers were similar among the groups G1, G3-ABV and G3-CVLP; however, there was a small increase in titers in group $\mathrm{G} 1$ in relation to group G3-ABV and this difference was not statistically significant $(p>0.05)$. Antibody titers against IBV in groups G1, G3-ABV and G3-CVLP were not different, showing that the immune response against IBV was not modified by NDV, results that are in accordance with Raggi \& Lee (1964) and Zygraich et al. (1973). 
Cardoso WM, Aguiar Filho JLC, Romão JM, Oliveira WF, Salles RPR, Teixeira RSC, Sobral MHR
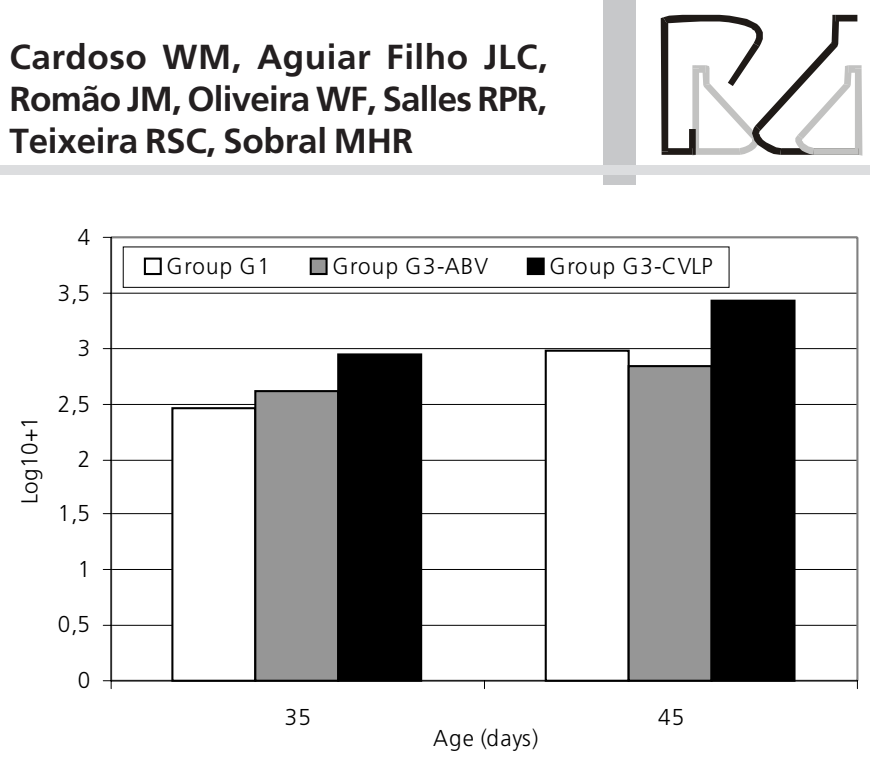

Graph 2 - Antibody titers against Infectious bronchitis virus of groups G1, G3-ABV and G3-CVLP at 35 and 45 days of age.

Graph 3 shows antibody levels against NDV of groups G2, G3-ABV and G3-CVLP at 35 and 45 days of age.

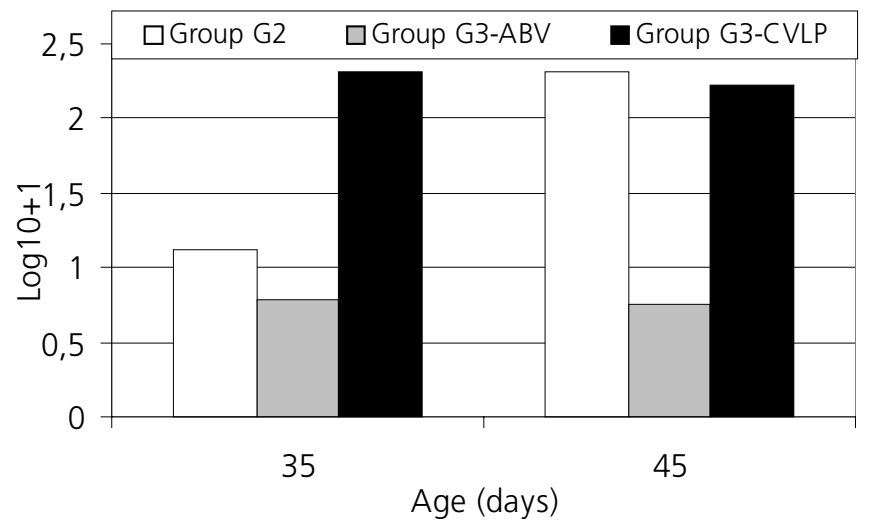

Graph 3 - Antibody titers against Newcastle disease virus of groups G2, G3-ABV and G3-CVLP at 35 and 45 days of age.

It is possible to observe an increase in the antibody titers of $\mathrm{G} 2$ at 35 to 45 days, although not statistically significant ( $p>0.05$ ). Group G2 was given only the vaccine against ND and presented higher antibody titers than G3-ABV, which was given a combined ND$I B$ vaccine. The low level of NBV antibodies in group G3-ABV might be explained by the interference between IBV and NDV. Many studies have reported this situation (Beard, 1967; Raggi \& Lee, 1963; Raggi \& Pignattelli, 1975; Yachida et al., 1986). According to Gelb et al. (2004), the interference between IBV and NDV occurs because both of them infect initially the epithelial cells of respiratory tract and then replicate in the cell cytoplasm. Studies performed by Montgomery et al. (1997) using combined or not IBV and NDV vaccinations showed that IBV vaccination cause a decrease in the capacity of the Harder gland $(\mathrm{HG})$ to
Effect of Associated Vaccines on the Interference between Newcastle Disease Virus and Infectious Bronchitis Virus in Broilers

respond to antigenic stimulus. Therefore, the lower immune response by HG induced by IBV may then decrease anti-NDV antibody levels if vaccination has been performed with IB-ND combined vaccines. Cook et al. (2001) reported that IBV not only interferes with NDV, but also that there was interference with another paramyxovirus, the avian pneumovirus. Graph 4 shows antibody titers to IBV and NDV at 35 and 45 days of age in the groups that received associated vaccines (G3-ABV and G3-CVLP).

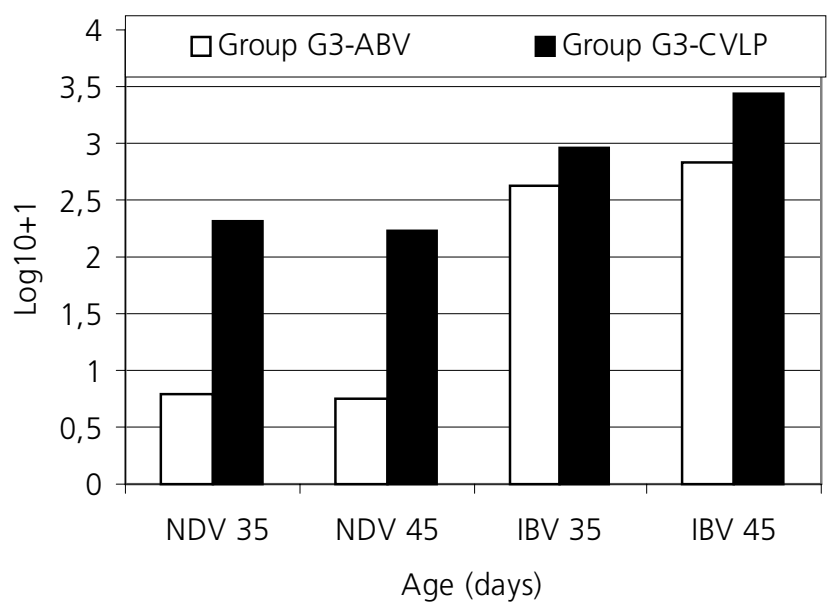

Graph 4 - Antibody titers against Newcastle disease virus and Infectious bronchitis virus in the groups submitted to associated vaccination.

Group G3-ABV presented lower IBV antibodies than the group G3-CVLP at 35 and 45 days of age; however, this difference was not statistically significant. This result shows that the fact of associating vaccines just before vaccination (group G3-ABV) or in the producing laboratory (group G3-CVLP) does not modify significantly the immune response against IBV. An opposite situation occurred regarding the immune response against NDV, because it was significantly modified by the use of the vaccines that were combined just before vaccination or those that had been combined in the producing laboratory. Group G3-ABV was immunized with the vaccines associated just before vaccination and showed NDV antibody titers that correspond to a situation of viral interference between IBV and NDV, because titers were lower than the titers shown by the group that was vaccinated only against ND (G2). Group G3-CVLP was given the commercial ND-IB-associated vaccine and presented NDV antibody titers similar to G2, demonstrating that there was no interference with the immune response. Some researchers have reported that there is no 
Cardoso WM, Aguiar Filho JLC, Romão JM, Oliveira WF, Salles RPR, Teixeira RSC, Sobral MHR interference between IBV and NDV (Zygraich et al., 1973 and Winterfield, 1984) and in our experiment it was observed that interference did not occur in the group that was given the IBV+NDV vaccine combined in the laboratory. This finding is very relevant because many producers use vaccines associated just before vaccination, what might be promoting viral interference; on the other hand, interference does not seem to occur when vaccines combined in the producing laboratory are used, as observed in our experiment. Therefore, the use of vaccines associated in the laboratory is a viable option because viral interference does not occur uniformly in the vaccinated flocks (Smith, 2002). Consequently, part of the birds are infected with the vaccinal strain of NDV and the viruses are then transmitted to the birds in which IBV interfered with the immune response against NDV, promoting an increase of the strain virulence by the reverse transmission of the vaccine. As a consequence, interference can result in high levels of stress, low production and an insufficient immunity against field strains of NDV. More studies should be performed to better understand the factors that inhibited the interference of IBV on the immune response against ND vaccine.

\section{CONCLUSION}

This study shows, as preliminary results, that polyvalent vaccination with vaccines associated before vaccination or in the laboratory during manufacturing is a factor that interferes on the development of the immune response against NDV or on the virus itself. The results indicate that the use of polyvalent vaccines $(\mathrm{IBV}+\mathrm{NDV})$ combined in the manufacturing laboratory can attenuate the interference between these viruses when compared to vaccines associated just before vaccination.

\section{REFERENCES}

Alexander DJ, Allan WH, Biggs PM, Beacewell CD, Darbyshire JH, Dawson OS, Harris HA, Jordan FTW, Macpherson I, McFerran JB, Randall CJ, Stuart JC, Swarbrick O, Wilding GP. A standard technique for haemagglutination inhibition test for antibodies to avian infectious bronchitis virus. Veterinary Record 1983; 113:64. Beard CW. Infectious bronchitis virus interference with Newcastle disease virus in monolayers of chicken kidney cells. Avian Diseases 1967; 11:399-406.

Bracewell CD, Dawson PS, Allan WH. Antibody responses to a live Newcastle disease vaccine when combined with a live infectious bronchitis vaccine. Veterinary Record 1972; 90:248-249.
Effect of Associated Vaccines on the Interference between Newcastle Disease Virus and Infectious Bronchitis Virus in Broilers

Cook JKA, Huggins MB, Orbell SJ, Mawditt K, Cavanagh D. Infectious bronchitis virus vaccine interferes with the replication of avian pneumovirus vaccine in domestic fowl. Avian Pathology 2001; 30: 233-242.

Gelb JJr, Campion L, Ladman B. Interferência na replicação entre os vírus da bronquite infecciosa e da doença de Newcastle. In: Anais vol.1 da Conferência Apinco de Ciência e Tecnologias Avícolas. São Paulo-Brasil. 2004 p. 63-70.

Gelb JJr, Jackwood MW. Infectious bronchitis: In: A laboratory manual for the isolation and identification of avian pathogens. In: $4^{\text {th }} \mathrm{ed}$. Swayne $D E$, Glisson JR, Jackwood MW, Pearson JE, Reed WM, eds. American Association of Avian Pathologists. Kendall/Hunt Publ. Co. 1998.

King DJ, Cavanagh D. Infectious bronchitis. In: Diseases of Poultry, $9^{\text {th }}$ ed., Calnek BW, Barnes HJ, Beard CW, Reid WM, Yoder HW.Jr. USA: Iowa State. University Press, Ames, lowa. 1991. p. 471-484.

Montgomery YRD, Maslin WR, Boyle CR. Effects of Newcastle disease vaccines and Newcastle disease/infectious bronchitis combination vaccines on the head-associated lymphoid tissues of the chicken. Avian Diseases 1997; 41(2):399-406.

Raggi LG, Pignattelli P. Identification of infectious bronchitis virus by interference with the B-1 isolant of Newcastle disease virus. Waxing and waning of interference. Avian Disease 1975; 19:334-342.

Raggi LG and Lee GG. Infectious bronchitis virus interference with growth of Newcastle disease virus. I. Study of interference in chicken embryos. Avian Diseases 1963; 7:106-122.

Raggi LG and Lee GG. Infectious bronchitis virus interference with growth of Newcastle disease virus. II. Interference in chickens. Avian Diseases 1964; 8:471-480.

SAS Institute, Inc (1999). SAS Online DocÒ Version 8.0 Cary, N.C.

Smith JA. Impact of mild Newcastle disease vaccines on control of IBV. Proc. $37^{\text {th }}$ National Meetings on Poultry Health and Processing 2002. Ocean City, Maryland. p. 31-44.

Thornton DH, Muskett JC. Effect of infectious bronchitis vaccination on the performance of live Newcastle disease vaccine. Veterinary Record 1975; 96:467-468.

Tu TD, Phuc KV, Dinh NTK, Quoc DN, Spradbrow PB. Vietnamese trials with a thermostable Newcastle disease vaccine (strain I2) in experimental and village chickens. Preventive Veterinary Medicine 1998; 34:205-214.

Winterfield RW. Vaccination of chickens with Newcastle disease and infectious bronchitis vaccines administered singly and in combination. Poultry Science 1984; 63:182-184.

Yachida S, Kuwahara E, Irirtani Y, Hayashi Y. In egg interference of embryo non-lethal avian infectious bronchitis viruses (IBV) with velogenic Newcastle disease virus and embryo adapted IBV. Research Veterinary Science 1986; 40:1-3.

Zygraich N, Vasoboinic E, Berge E. The use of a combined vaccine against Newcastle disease and infectious bronchitis. Veterinary Record 1973; 93:516-518. 